\title{
OPTIMIZATION OF OPERATING CONDITIONS IN A LABORATORY SOFC TESTING DEVICE
}

\author{
OPTIMIZACIJA OBRATOVALNIH RAZMER LABORATORIJSKE \\ GORIVNE CELICE SOFC
}

\author{
Tina Skalar, Martin Lubej, Marjan Marinšek \\ University of Ljubljana, Faculty of Chemistry and Chemical Technology, Večna pot 113, 1000 Ljubljana, Slovenia \\ marjan.marinsek@fkkt.uni-lj.si \\ Prejem rokopisa - received: 2014-08-22; sprejem za objavo - accepted for publication: 2014-12-01
}

doi:10.17222/mit.2014.209

\begin{abstract}
Solid-oxide fuel cells (SOFCs) are devices that convert chemical energy into electrical energy. They are assembled from three solid components, which, in principle, differ in their thermal expansion coefficients. These differences may cause residual stresses during an operation and consequently lead to physical damage of a cell. From this perspective, the reliability of an operating SOFC is seriously dependent on the thermal stress built inside the multi-layer structure. In this work, some operating conditions in the SOFCs based on an SDC electrolyte, an LSM cathode and a Ni-SDC anode were investigated both experimentally and theoretically. Within the theoretical analysis, the residual stresses and temperature profiles inside an operating cell were modelled with the finite-element method. The results of the mathematical modelling of the warm-up, steady-state or cooldown periods were used to optimize the cell geometry and the thickness of individual cell layers, and to determine the most appropriate operating cell conditions. In order to experimentally confirm some theoretical calculations, a new SOFC testing system was developed, which enabled relatively easy assembling and dismantling as well as quick changes in the operating conditions (temperature, atmospheres). Based on the modelling results, optimization of the operating conditions was proposed in order to reduce the thermal stresses built in the materials.
\end{abstract}

Keywords: SOFC, modelling, temperature gradient, thermal stress, optimization

Visokotemperaturne gorivne celice pretvarjajo kemično energijo preko katalitskih reakcij v električno energijo. Sestavljene so iz treh trdnih (keramičnih) materialov, ki imajo različne temperaturne razteznostne koeficiente. Različni raztezki materialov povzročajo mehanske napetosti, kar ima lahko za posledico degradacijo (razpad) strukture večslojnega sistema. Zanesljivost gorivne celice je tako odvisna od ustvarjenih mehanskih napetosti v materialih. V tem delu smo raziskovali razmere pri obratovanju tako eksperimentalno kot teoretično za večplastno preizkusno tableto. Zapisali smo matematični model za opis generiranih mehanskih napetosti med segrevanjem, v stacionarnem stanju in med ohlajanjem ter z metodo končnih elementov prišli do numerične rešitve modela. Dobljene rezultate smo uporabili pri optimizaciji geometrije celice in debeline posameznih plasti $\mathrm{v}$ večplastni tableti. Za eksperimentalno preverjanje dobljenih rezultatov modeliranja smo razvili nov preizkusni sistem, ki omogoča relativno hitro sestavljanje in razstavljanje ter hitro spremembo obratovalnih razmer (temperature, atmosfere). Na osnovi dobljenih rezultatov je bila predlagana optimizacija preizkusnega sistema za zmanjšanje mehanskih napetosti $\mathrm{V}$ materialih.

Ključne besede: SOFC, modeliranje, temperaturni gradienti, termične napetosti, optimizacija

\section{INTRODUCTION}

Solid-oxide fuel cells (SOFCs) are highly promising and environmentally friendly energy converters with a high energy-conversion efficiency, converting chemical energy of reactants into electrical energy. ${ }^{1-4}$

SOFCs, as any other batteries, consist of three different layers, called SOFC membranes, i.e., an electrolyte, an anode and a cathode, and operate at temperatures between $600{ }^{\circ} \mathrm{C}$ and $1000{ }^{\circ} \mathrm{C}$. As an electrolyte, samariadoped ceria (SDC), a well-known advanced ceramic material, was recently proposed to reduce the SOFC operating temperatures due to its high oxygen-ion conductivity. ${ }^{5-9}$

A cermet of metallic nickel and ceramic, i.e., SDC (Ni-SDC), is most commonly used as the anode material in a SOFC. The main reasons for the selection of $\mathrm{Ni}-$ SDC are its thermal-expansion coefficient that is comparable with the SDC electrolyte, a relatively good ionic and electronic conductivity and a catalytic activity acceptable for hydrogen or hydro-carbon electro-oxidation. On the cathode side, doped lanthanum manganite (i.e., lanthanum strontium manganite, LSM) is most commonly used. ${ }^{10-13}$

Since SOFC membranes, in principle, are composed of various materials, their thermal-expansion coefficients (TEC) may differ. For instance, the TEC of an anode cermet is normally somewhat higher than those of the electrolyte and cathode. These differences in the TECs may build stresses in the SOFC membrane during a temperature alteration and, consequently, lead to a SOFCmembrane delamination. From this perspective, the reliability of an SOFC membrane is seriously dependent on the SOFC operating conditions, especially during its heating to the operating steady-state conditions or cooling down to room temperature. ${ }^{14-18}$

One way to approach the problem of determining the optimum operating conditions of an SOFC system is to 
employ mathematical modelling. In this way, several parameters, i.e., temperature profiles and stress fields, can be followed without performing complicated and lengthy SOFC experimental tests. The finite-elementmethod (FEM) modelling was already successfully used by several authors to address similar engineering problems. ${ }^{19-22}$

With the FEM, a continuous problem can be transformed into a discrete problem with a finite number of degrees of freedom. . $^{23-25}$

In this paper, the optimum operating parameters in which an SOFC multilayer membrane is not exposed to a critical thermal stress caused by temperature gradients are determined. Additionally, the problem of the optimum cell geometry and the thicknesses of individual cell layers during the warm-up or steady-state periods is addressed.

\section{EXPERIMENTAL PROCEDURE}

\subsection{Material and membrane preparation}

An electrolyte made of samarium-doped ceria (SDC) or an anode made of nickel oxide samarium-doped ceria (NiO-SDC) and a lanthanum manganite (LSM) cathode were synthesized using the modified Pechini method and carbonate precipitation, respectively. The exact synthesis procedures are described in ${ }^{26,27}$. Before a multi-layer membrane was prepared, a supporting layer (electrolyte or anode) was pressed into a tablet and pre-sintered at $1000{ }^{\circ} \mathrm{C}$ in air in order to ensure the mechanical strength for the screen printing of other layers. The thickness of the screen-printed layers was $20 \mu \mathrm{m}$. If an anodesupported system was prepared, an SCD electrolyte was first screen-printed on a NiO-SDC pre-sintered anode. Such a multi-layer system was co-sintered at $1250{ }^{\circ} \mathrm{C}$ in order to form a good contact between the layers. The same procedure was used for electrolyte-supported systems with an exception, in which an SDC was first pre-sintered and a NiO-SDC was then screen printed and co-sintered. After the co-sintering, an LSM cathode was screen printed on the electrolyte, opposite to the anode side. Such a multi-layer system was again co-sintered at $1200{ }^{\circ} \mathrm{C}$.

\subsection{Testing-system assembly}

The testing system (Figure 1) was composed of a multilayer tablet (anode/electrolyte/cathode), which was sealed in steatite ceramics. The steatite ceramics was placed between two quartz tubes to prevent the mixing of the inner and outer atmospheres, or the mixing of the cathode oxidative and anode reductive atmospheres (Viton o-rings were used for sealing). The whole system was then placed into another protective quartz tube. Heaters were mounted outside the protective quartz tube. The inner and outer quartz tubes were embedded into a stainless-steel (1.4404) case and fixed to the construction with four screws. The testing system was isolated with a $\alpha$-alumina insulation $2 \mathrm{~cm}$. The $\mathrm{NiCr}-\mathrm{Ni}$ thermocouple was pushed through a small hole in the stainless-steel case and coupled with the display.

\subsection{Used model}

The gas flow and temperature distribution were simulated using numerical methods. The transport of mass and energy was calculated using the continuum theory. ${ }^{28}$ The heat was introduced as a homogeneous-volume heat source at the heating element. The heat was dissipated at the outer boundaries with a heat flux corresponding to the wall temperature and the heat-transfer coefficient obtained with the Churchill and Chu correlation. ${ }^{29}$ The system of differential equations was solved utilizing the finite-elements method in a 2D axisymmetric geometry, and the stationary state was achieved at the $35^{\text {th }}$ iteration.

The mechanical stress inside the tested membrane was calculated using a linear elastic material model ${ }^{30}$ in combination with the thermal expansion. The reference temperature was defined as the temperature, at which there is no stress in the material. The mechanical model was solved utilizing the finite elements in a 2D axisymmetric geometry.

For all the materials, the average emissivity $(\varepsilon)$ of 0.8 was used. Young's modulus $(E)$, Poisson's ratio $(v)$, the density $(\rho)$, the thermal-expansion coefficient $(\alpha)$ were $200 \cdot 10^{9} \mathrm{~Pa},{ }^{23} 0.32,{ }^{23} 7600 \mathrm{~kg} / \mathrm{m}^{3}, 11.5 \cdot 10^{-6} \mathrm{~K}^{-1},{ }^{31} 55$. $10^{9} \mathrm{~Pa},{ }^{23} 0.17,{ }^{27} 8900 \mathrm{~kg} / \mathrm{m}^{3}, 13 \cdot 10^{-6} \mathrm{~K}^{-123}$ and $40 \cdot 10^{9}$ $\mathrm{Pa},{ }^{31} 0.25,{ }^{31} 6500 \mathrm{~kg} / \mathrm{m}^{3},{ }^{31} 11.4 \cdot 10^{-6} \mathrm{~K}^{-1}{ }^{31}$ for the SDC, $\mathrm{NiO}-\mathrm{SDC}$ and the LSM cathode, respectively. The densities for the anode and electrolyte materials were calculated as Archimedes' densities from the dimensions of the sintered bodies.

\section{RESULTS AND DISCUSSION}

Finding the optimum design and operating conditions makes the SOFC testing rather time-consuming. Moreover, in order to track various parameters during an SOFC continuous run, the testing systems are usually rather complicated and difficult to assemble, making visual observing of a tested multilayer SOFC membrane practically impossible. For this reason, a new SOFC testing system was developed, in which a multilayer tablet (anode/electrolyte/cathode) is sealed in a steatite-ceramics holder and embedded into a double quartz-glass tube, which is then put into a tube oven (as presented in the experimental work, Figure 1).

Such a system has a rather simple design, is easy to assemble/dismantle or manipulate, and enables quick changes in the operating conditions (temperature, atmospheres). The true advantage of the simplified SOFC design, however, is the fact that it enables the start of new experiments in short cycles, thereby overcoming the time-consuming difficulty of more complex testing 


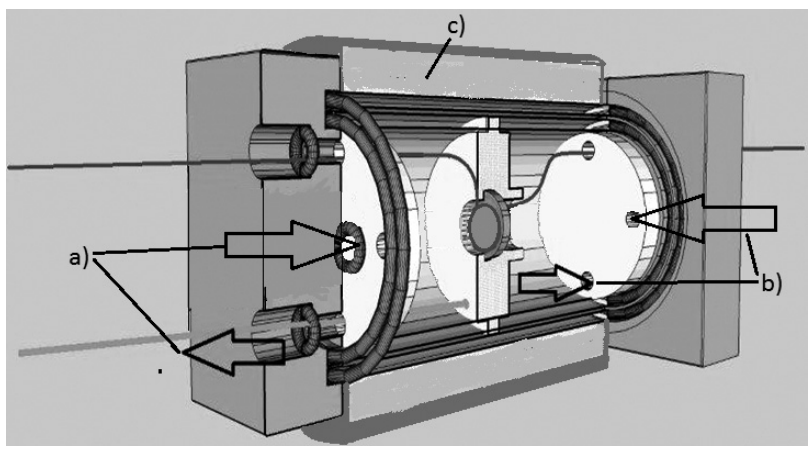

Figure 1: Scheme of a test cell: a) anode inlet/outlet atmosphere, b) cathode inlet/outlet atmosphere and c) tube oven

Slika 1: Shema preizkusne celice: a) vpih in izpih anodnega plina, b) vpih in izpih katodnega plina in c) obodni grelnik

systems. However, short testing cycles are always related to rapid temperature changes inside the testing system. It is well known that the temperature increases or decreases in a ceramic multilayer system with different temperature-expansion coefficients, thereby building stresses that may initiate crack formation, which eventually leads to a complete system delamination. In order to avoid such an undesirable multilayer degradation, two approaches are possible: i) numerous tests to determine the temperature regime during a testing cycle, or ii) employing a mathematical simulation model and predicting the temperature gradients as well as the built stress fields in the tested membrane, as was the case in this work.

The first addressed question is the position of the heating elements in the testing system as the heating elements may be placed inside or outside the tested SOFC cell. Positioning the heating elements inside each of the SOFC chambers (the cathode and anode sides) has the advantage of a very fast temperature change, as shown in our previous work. ${ }^{24}$ However, the heating of the individual chambers and the tested membrane positioned between both chambers with two point sources placed above and below the membrane also causes some undesired temperature gradients in the membrane, where the center of the membrane is always hotter than its outer regions. These temperature gradients are the greatest during the membrane's rapid heating but cannot be eliminated completely even in the steady operating state due to the heat exchange between the SOFC testing cell and its surroundings. For this reason, the heating elements were placed around the double quartz tube. In such a modification, additional heat-insulating layers between the heater and the membrane are introduced (the quartz tube itself). However, due to the powerful heating elements, rapid temperature changes are still possible (Figure 2) even with the heaters placed outside the quartz tubes.

The newly developed SOFC testing design enables the work with multi-layer membrane systems of various shapes, e.g., a cube or a cylinder. Altering the shape of a multi-layer system also causes some changes in the temperature distribution in the heated membrane. The tem-

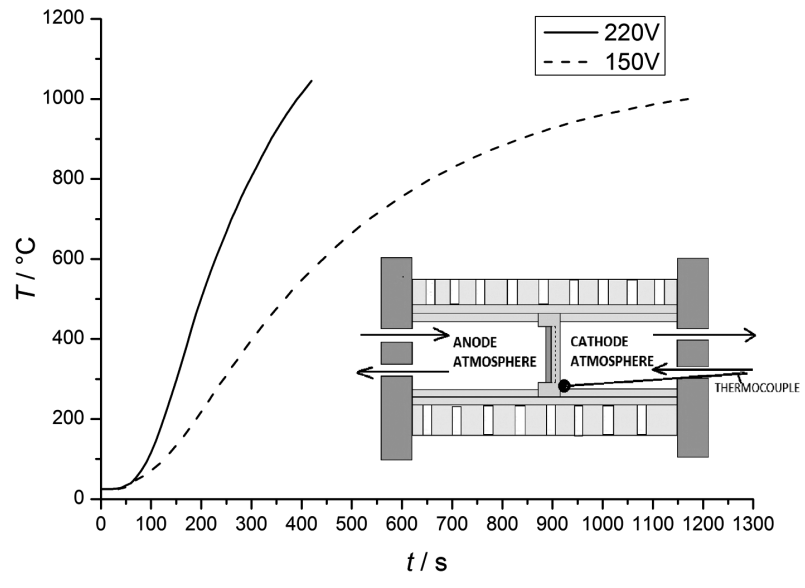

Figure 2: $T$ versus $t$ relationship measured at the inner side of the quartz tube during the SOFC testing-system start-up; the small insert represents the measuring point

Slika 2: Odvisnost $T$ od $t$, merjena na notranji strani kremenove cevi pri zagonu sistema SOFC; izrez prikazuje točko merjenja temperature

perature gradients are much more pronounced alongside the radius of the membrane due to the relative position of the heating elements and practically negligible alongside the $z$-axis. Furthermore, the heating mode of the multilayer membrane suggests that the biggest temperature gradients appear during the membrane heating (shortly after the heaters start to heat up the outer quartz tube) and gradually declines when the temperature of the inner chambers of the SOFC testing system approaches its final value. According to the results of the mathematical modelling, the maximum temperature gradients from the membrane center to its edge $\Delta T_{1}$ are $\approx 90{ }^{\circ} \mathrm{C}$ or $\approx 75{ }^{\circ} \mathrm{C}$ for cube or cylinder membranes, respectively (Figure 3). This rather noticeable difference in the maximum temperature gradients is introduced by the design of the SOFC testing system itself. Since the heating elements are positioned cylindrically around the quartz tubes, the outer positions of the cube membrane are unevenly distant from the heaters and thus exposed to various heat fluxes. At the same time, due to the relatively thin multi-layer membrane $(\approx 3 \mathrm{~mm})$, the temperature gradient alongside the $z$-axis, $\Delta T_{2}$, is only $2.2^{\circ} \mathrm{C}$ for both membrane designs. Since the temperature gradients inside the
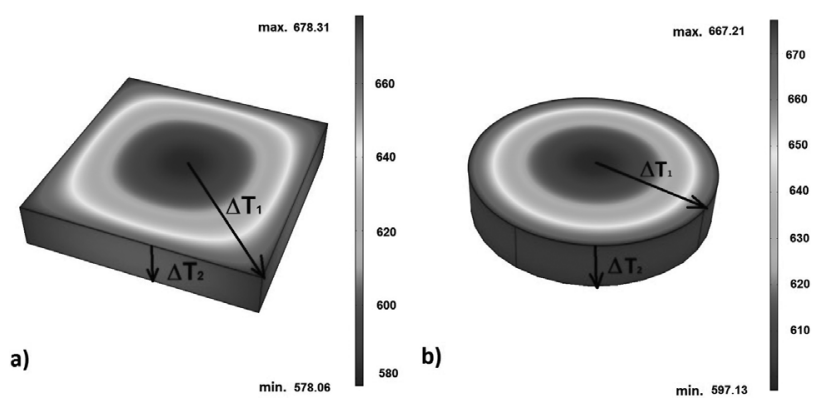

Figure 3: Temperature distribution in the tested membranes: a) cubic membrane and b) cylindrical membrane

Slika 3: Porazdelitev temperature v preizkusni membrani: a) v obliki kvadra in b) v obliki valja 

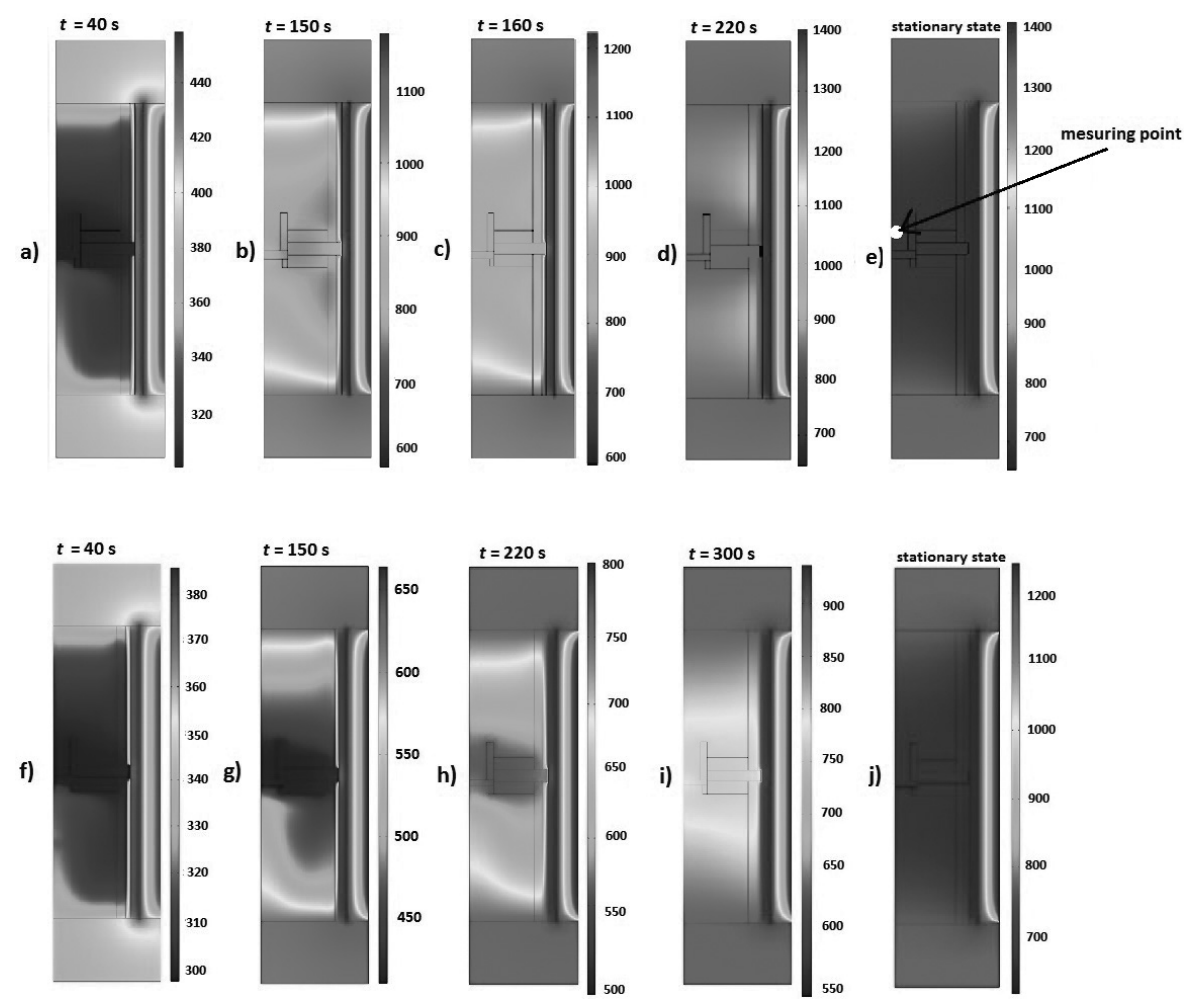

Figure 4: Temperature distributions in both inner chambers of the SOFC testing system and throughout the membrane at various times presented in a vertical plane: a) to e) the heating element is powered with $220 \mathrm{~V}, \mathrm{f}$ ) to j) the heating element is powered with $150 \mathrm{~V}$

Slika 4: Porazdelitev temperature, prikazana v vertikalni ravnini v preizkusni celici po različnih časih segrevanja: a) do e) pri nazivni napetosti grelnika $220 \mathrm{~V}$, f) do j) pri nazivni napetosti grelnika $150 \mathrm{~V}$

tested membrane are one of the prime causes for the induced thermal stresses (as discussed later) a cubic membrane is much more susceptible to potential cracking. For this reason, such membranes are omitted from further modelling.

Starting a new testing cycle and heating up the membrane is a critical point that decisively influences the survival chances of a multi-layer membrane. In order to obtain a greater insight into the circumstances during the system heating, the temperature distribution inside the testing system (including the tested membrane) is mathematically modelled at several pre-chosen times and presented in Figure 4. For mathematical modelling, a multilayer electrolyte-supported membrane with thicknesses of the individual layers (anode/electrolyte/cathode) being $20 \mu \mathrm{m} / 2000 \mu \mathrm{m} / 20 \mu \mathrm{m}$, respectively, is assumed. From the sequence of the pictures showing the temperature distribution, it is evident that the temperature inside the testing system starts to rise due to the hot quartz tube that heats the adjacent gas and causes its circulation. The system design, where a stainless-steel case is used to cover the quartz tubes at both ends, is the reason for further temperature increases. More precisely, stainless steel heats up relatively quickly, serving as an additional heat source for the gases inside individual chambers causing their increased circulation. The vertical position of the testing system forces the hot gases to flow alongside the $z$-axis. Due to this vertical flow of the hot gas inside the bottom chamber, the bottom plane of the membrane heats up more quickly than its top plane, causing temperature gradients in the vertical cross-section throughout the membrane (the temperature distributions at various times throughout the membrane are presented in Figure 4). At some critical point, the temperature gradient $\Delta T_{2}$ in the membrane is maximal (Figures $\mathbf{4 c}$ and $\mathbf{4 h}$ ). This critical time was determined as $160 \mathrm{~s}$ or $300 \mathrm{~s}$ if the heating element worked with its maximum power (powered with $220 \mathrm{~V}$ ) or with just $46 \%$ of its maximum power (powered with $150 \mathrm{~V}$ ), respectively. In the latter case, the temperature inside the SOFC testing system typically rises more slowly, also reducing the built temperature gradients $\Delta T_{1}$ and $\Delta T_{2}$ (Figure 5). Since the membrane is a multilayer system in which individual layers exhibit different temperature-expansion coefficients, temperature gradient $\Delta T_{2}$ is particularly important. Dissimilar temperature-expansion coefficients, together with temperature gradient $\Delta T_{2}$, may introduce a situation in which the expansion of an individual layer during the membrane heating differs from the expansion of the adjacent layer to a degree that causes a membrane delamination. After the critical time, temperature gradient $\Delta T_{2}$ slowly diminishes and becomes negligible in the steady operating state (Figures $4 \mathbf{e}$ and $\mathbf{4 j}$ ).

A verification of the modelled temperature fields was conducted via additional temperature measurements 
using NiCr-Ni thermocouples. The measuring points at each specific time are marked in Figure 4. It is evident that the mathematical model used describes the temperature field in the tested system rather well (Table 1). Temperature mismatches between the modelled and measured temperatures in either point and at each specific time do not exceed $8{ }^{\circ} \mathrm{C}$. These slight mismatches are ascribed to a somewhat difficult positioning of the thermocouple at the predetermined point and in the dynamic temperature field (the response time of the $\mathrm{NiCr}-\mathrm{Ni}$ thermocouple is $\approx 2 \mathrm{~s}$ ).

Table 1: Comparison between modelled and measured temperatures (marked point in Figure 4) in the tested system at various heating times

Tabela 1: Primerjava modelirane in merjene temperature (točka merjenja je označena na sliki 4) v preizkusnem sistemu pri različnih časih segrevanja

\begin{tabular}{|c|c|c|c|c|c|}
\hline \multicolumn{3}{|c|}{$220 \mathrm{~V}$} & \multicolumn{3}{c|}{$150 \mathrm{~V}$} \\
\hline$t_{\text {heating }} / \mathrm{s}$ & $\begin{array}{c}T_{\text {modelled }} \\
/ \mathrm{K}\end{array}$ & $\begin{array}{c}T_{\text {measured }} \\
/ \mathrm{K}\end{array}$ & $t_{\text {heating }} / \mathrm{s}$ & $\begin{array}{c}T_{\text {modelled }} \\
/ \mathrm{K}\end{array}$ & $\begin{array}{c}T_{\text {measured }} \\
/ \mathrm{K}\end{array}$ \\
\hline 40 & 306 & 304 & 40 & 304 & 303 \\
\hline 160 & 882 & 877 & 300 & 756 & 750 \\
\hline 7200 & 1379 & 1371 & 7200 & 1233 & 1227 \\
\hline
\end{tabular}

Another important issue addressed by mathematical modelling is the fluid-velocity simulation inside both SOFC chambers (Figure 6). According to the simulation, the causes of the gas turbulence in the SOFC chambers are the fresh-gas inlet and the created temperature gradients. The cylindrical design of the SOFC testing system causes the gas velocity to be the highest close to the chamber center $\left(\approx 2.2 \cdot 10^{-3} \mathrm{~m} \mathrm{~s}^{-1}\right)$ and relatively low near the surface of the tested membrane. The complex movement path of gas molecules is indicated by their trajectories. The fluid-velocity pictures inside the anode and cathode chambers, however, are not mirror-inverted. Due to the vertical rise of the hot gases, the region of

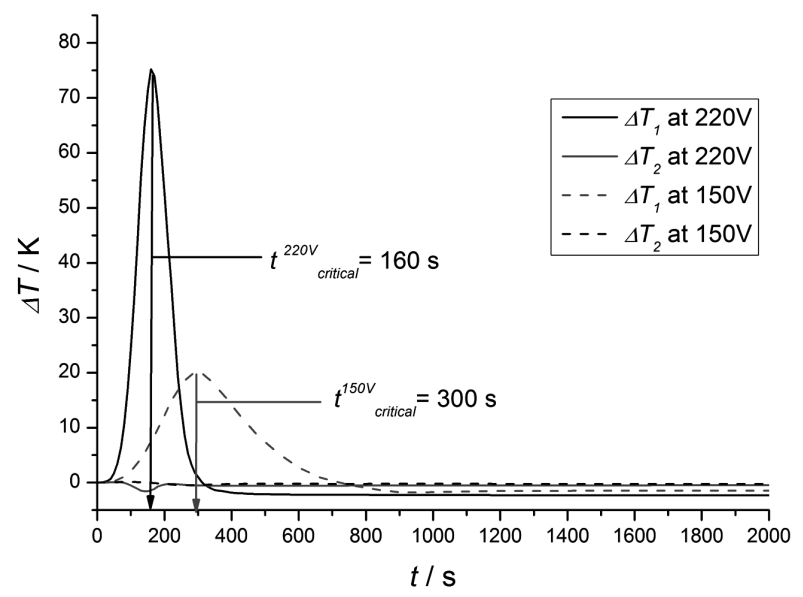

Figure 5: Relationships of induced temperature gradients $\Delta T_{1}$ and $\Delta T_{2}$ with $t$, presented in a vertical plane through the multi-layer membrane

Slika 5: Inducirani temperaturni gradienti $\Delta T_{1}$ in $\Delta T_{2} \mathrm{v}$ odvisnosti od časa $t$, prikazani v vertikalni ravnini skozi večplastno membrano high-gas velocity in the bottom chamber is closer to the membrane relative to the top chamber. Despite the lowest gas velocity of $\approx 3 \mu \mathrm{m} \mathrm{s}^{-1}$ near the membrane surface (10 $\mu \mathrm{m}$ from the surface), no gas pockets with a stationary atmosphere could be observed, which is important from the practical viewpoint of an operating SOFC. Only dynamic atmosphere conditions at the membrane surface may deliver fresh reactants to the diffusion layer of the porous-membrane catalyst and remove gaseous products. Additionally, it can be presented with the mathematical modelling that the introduction of fresh cold gases negligibly influences the temperature fields inside both of the SOFC chambers. The gases entering the anode or cathode chambers are practically instantly heated up to the temperature of the chambers operating at a steady state. This fact is not surprising since the gas inlets are relatively low $(\approx 15 \mathrm{~mL}$ $\mathrm{min}^{-1}$ ) while the chambers are relatively large and only $\approx 72 \mathrm{~W}$ is needed to heat a gas flow of $15 \mathrm{~mL} \mathrm{~min}^{-1}$ from room temperature to the chamber temperature.

In an SOFC multi-layer system, in principle, three different materials are combined in a single membrane. Since the temperature-expansion coefficients of individual layers are not identical, any temperature alteration may build a stress alongside a phase border and, consequently, cause a delamination of the multi-layer membrane. The first critical point in the lifecycle of a multilayer membrane arises during its preparation. Specifically, the membrane is prepared by co-sintering all three layers and, subsequently, reducing $\mathrm{NiO}$ to $\mathrm{Ni}$ in the anode composite. During the sintering, a plastic deformation of the material is allowed. From this perspective, it can be assumed that the system is stress-free at the sintering temperature. In the testing system, the stress-free state is adopted at $1250{ }^{\circ} \mathrm{C}$, at which the $\mathrm{NiO} / \mathrm{SDC}$

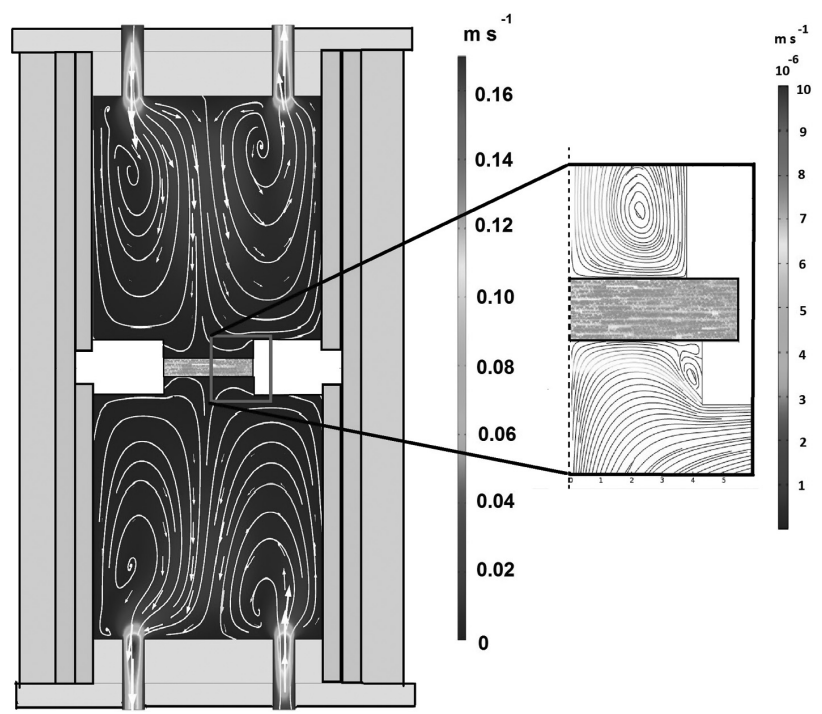

Figure 6: Fluid-velocity simulation together with gas trajectories in both inner chambers

Slika 6: Simulacija gibanja plinov skupaj s trajektorijami plina v notranjih prostorih preizkusnega sistema 
anode, the SDC electrolyte, and the LSM cathode are co-sintered. The subsequent reduction of $\mathrm{NiO}$ to $\mathrm{Ni}$ should not induce any additional stress since $\mathrm{Ni}$ may undergo a plastic deformation. Thermal stresses in the multilayer system start to build up below the plasticdeformation temperature, reaching their peak at room temperature. ${ }^{32}$ Depending on the temperature-expansion coefficients of the adjacent layers $\left(13 \cdot 10^{-6} \mathrm{~K}^{-1}\right.$, $11.5 \cdot 10^{-6} \mathrm{~K}^{-1}$ and $11.4 \cdot 10^{-6} \mathrm{~K}^{-1}$ for $\mathrm{Ni} / \mathrm{SDC}, \mathrm{SDC}$ and LSM, respectively) these built-up stresses may be as high as several hundred $\mathrm{MPa}$ and may cause cracks to form.

The residual stresses after the membrane preparation are practically impossible to measure directly; however, by adopting an appropriate mathematical model, they can be calculated rather easily. Thus, if Ni/SDC-SDCLSM $(20 \mu \mathrm{m}-3000 \mu \mathrm{m}-20 \mu \mathrm{m})$ is cooled down to room temperature (after the reduction of $\mathrm{NiO}$ to $\mathrm{Ni}$ ) the residual thermal stresses are calculated as $\approx 130 \mathrm{MPa}$ for $\mathrm{Ni} / \mathrm{SDC}$ of the anode layer, close to the anode-electrolyte phase boundary, $\approx 9 \mathrm{MPa}$ for the electrolyte adjacent to the anode layer, and the lowest stress for LSM $(<1 \mathrm{MPa})$, at the SDC-LSM phase boundary. Together with the calculated number, the nature of the built stresses must also be taken into consideration. Due to a higher thermal-expansion coefficient, the Ni/SDC layer tends to shrink more than the SDC electrolyte, while LSM shrinks to approximately the same degree as SDC. In a hypothetical situation in which two layers subjected to uneven material shrinkage have approximately the same thickness, the induced stress should bend the bilayer system where the layer with the smaller shrinkage forms a concave surface at the phase boundary. In view of the chosen set of materials and the actual membrane design, the degree of shrinkage suggests that the stress in the anode layer in the cooled-down state is always tensile, while the electrolyte layer is under compression. Therefore, at room temperature, the anode appears to be the potential weak point of the multi-layer system. However, the maximum calculated tensile stress in the anode layer does not exceed the Ni/SDC tensile strength, which is $\approx 150 \mathrm{MPa} .{ }^{33}$ As the final result, the calculated values suggest that the multi-layer system should survive the first thermal cycle (sintering and reduction), which is also in accordance with practical observations.

During the repeated heating from room temperature to operating temperatures $\left(700-800{ }^{\circ} \mathrm{C}\right)$ it would be expected that the stresses in the multi-layer membrane slowly diminish since the increasing temperature brings the system closer to a stress-free state. However, it turns out that the picture of the stresses built during the heating is far more complex. As mentioned previously, the membrane is not heated up evenly. Instead, the outer layers of the membrane are heated up faster than the inner layers due to the circulating hot gases in the top (anode) and bottom (cathode) chambers. Due to these temperature gradients and the fact that the layers have different temperature-expansion coefficients, it appears that the center of the membrane (relative to the membrane outskirts) is always at higher loads regarding the built stresses (Figure 7). The adopted mathematical model predicts that the maximum stress is created at the critical time when the temperature gradient $\Delta T_{2}$ is maximal. In a situation in which the stress in the membrane (a thickness of $20 \mu \mathrm{m} \mathrm{Ni} / \mathrm{SDC}, 2000 \mu \mathrm{m}$ SDC, $20 \mu \mathrm{m}$ LSM, a diameter $\varnothing=11 \mathrm{~mm}$, the critical time $t=160 \mathrm{~s}$ ) is modelled, it can be calculated that any given temperature above the cooled-down state causes some relaxation and reduces the tensile stress in the anode layer. In contrast, the relatively thick electrolyte adjacent to the anode stretches unevenly in accordance with the created temperature gradient. In addition, the stress in the electrolyte layer near the anode/electrolyte phase boundary is also built up due to anode stretching, meaning that the electrolyte is under the tensile stress at critical times. The absolute value of the induced tensile stress in the electrolyte layer after $\approx 160 \mathrm{~s}$ of the heating at the maximum power $(220 \mathrm{~V})$ is $\approx 70 \mathrm{MPa}$ (Figure $7 \mathbf{a})$. This value exceeds the tensile strength of SDC, which is $53 \mathrm{MPa}{ }^{34}$ When the maximum tensile strength is surpassed, the material is prone to cracking. If the heating power is reduced ( $46 \%$ of the heater's maximum power; the heaters are powered with $150 \mathrm{~V}$ ), the induced tensile stress in the electrolyte at the critical time $(\approx 300 \mathrm{~s})$ decreases to 27 $\mathrm{MPa}$, which is acceptably low and demonstrates that a somewhat slower heating rate significantly reduces the stress load in the membrane.

Another interesting situation is demonstrated in Figure $\mathbf{7 b}$, in which the membrane diameter is increased to $\varnothing=18 \mathrm{~mm}$. According to the mathematical modelling, membranes with larger diameters will build higher stresses under the same heating conditions. The absolute value of the induced tensile stress in the electrolyte layer at the critical time $(\approx 160 \mathrm{~s})$ thus increases to $\approx 83 \mathrm{MPa}$

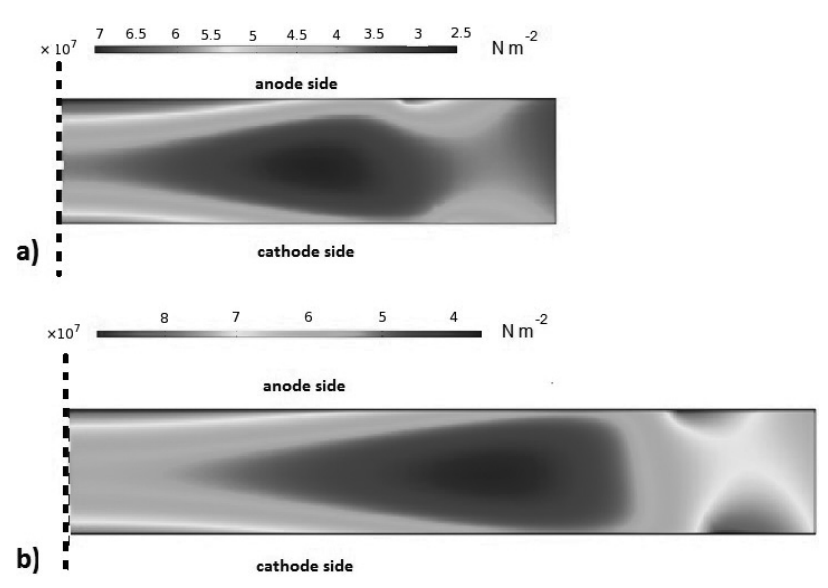

Figure 7: Induced stresses in the membrane $(20 \mu \mathrm{m}-2000 \mu \mathrm{m}-20 \mu \mathrm{m}$, $t=160 \mathrm{~s}$ ) presented in a vertical plane: a) $\varnothing=11 \mathrm{~mm}$, b) $\varnothing=18 \mathrm{~mm}$ Slika 7: Inducirane napetosti v membrani $(20 \mu \mathrm{m}-2000 \mu \mathrm{m}-20 \mu \mathrm{m}, t=$ $160 \mathrm{~s}$ ), predstavljene v vertikalni ravnini: a) $\varnothing=11 \mathrm{~mm}$, b) $\varnothing=18 \mathrm{~mm}$ 
(the heaters powered with $220 \mathrm{~V}$ ) or $\approx 30 \mathrm{MPa}$ (the heaters powered with $150 \mathrm{~V}$ ).

Since membranes in modern SOFC systems may be designed as anode- or electrolyte-supported, the next logical task addresses the thicknesses of individual layers and the associated stress load in the membrane during the heating. This question was approached by conducting a series of mathematical modelling tasks, in which the built stresses versus the thicknesses of individual layers were calculated (Figure 8). The investigated scenario includes the membrane discs $(\varnothing=11 \mathrm{~mm})$ in which the thicknesses of the Ni/SDC anode or SDC electrolyte layers vary from $20 \mu \mathrm{m}$ to $3000 \mu \mathrm{m}$ (the thickness of the LSM cathode layer is constant, being $20 \mu \mathrm{m}$ ). Since the most challenging conditions, with respect to the built-up stress, occur at the critical time of the heating when the temperature gradients are the highest $(160 \mathrm{~s}$ or $300 \mathrm{~s}$ if the heaters are powered with $220 \mathrm{~V}$ or $150 \mathrm{~V}$, respectively), only the maximum stresses built in the individual layers are presented. According to the results, several
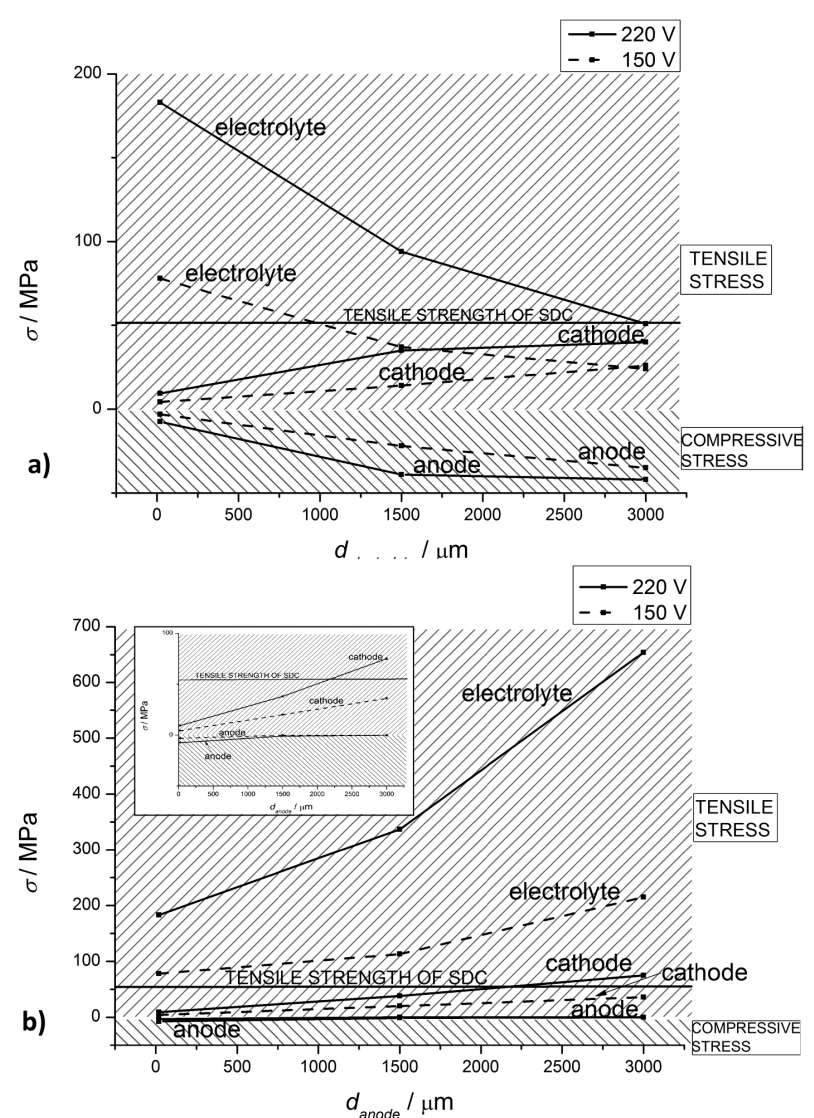

Figure 8: Maximum stresses in the multi-layer SOFC membrane as a function of: a) electrolyte thickness $\left(d_{\text {anode }}=d_{\text {cathode }}=20 \mu \mathrm{m}\right.$, $\emptyset_{\text {membrane }}=11 \mathrm{~mm}, t_{\text {heating }}=160 \mathrm{~s}$ at $220 \mathrm{~V}$ or $t_{\text {heating }}=300 \mathrm{~s}$ at 150 $\mathrm{V})$ and $\mathrm{b})$ anode thickness $\left(d_{\text {electrolyte }}=d_{\text {cathode }}=20 \mu \mathrm{m}, \emptyset_{\text {membrane }}=\right.$ $11 \mathrm{~mm}, t_{\text {heating }}=160 \mathrm{~s}$ at $220 \mathrm{~V}$ or $t_{\text {heating }}=300 \mathrm{~s}$ at $150 \mathrm{~V}$ )

Slika 8: Maksimalna napetost $v$ večslojni SOFC-membrani kot funkcija: a) debeline elektrolita $\left(d_{\text {anoda }}=d_{\text {katoda }}=20 \mu \mathrm{m}, \emptyset_{\text {membrana }}=\right.$ $11 \mathrm{~mm}, t_{\text {segr. }}=160 \mathrm{~s}$ pri $220 \mathrm{~V} \mathrm{oz} . t_{\text {segr. }}=300 \mathrm{~s}$ pri $\left.\left.150 \mathrm{~V}\right), \mathrm{b}\right)$ debeline anode $\left(d_{\text {elektrolit }}=d_{\text {katoda }}=20 \mu \mathrm{m}, \emptyset_{\text {membrana }}=11 \mathrm{~mm}, t_{\text {segr. }}=160 \mathrm{~s}\right.$ pri $220 \mathrm{~V} \mathrm{oz} . t_{\text {segr. }}=300 \mathrm{~s}$ pri $150 \mathrm{~V}$ ) distinct features can be easily identified. Firstly, during the heating, the stress in the anode is always compressive, while the stresses in the electrolyte and cathode are tensile. Secondly, the stress in one component decreases with an increase in its thickness, when the thicknesses of the other two components are fixed. In addition, decreases in the compressive stress in the anode layer cause increases in the tensile stress in both the electrolyte and the cathode and vice versa. Thirdly, the thicknesses of the anode and the electrolyte have a pronounced influence on the stresses in the adjacent layers. Fourthly, due to very similar temperature-expansion coefficients of SDC and LSM, the tensile stress in the cathode layer never exceeds its tensile strength, which is assumed as $138 \mathrm{MPa}^{34}$

The absolute values of the calculated stress also reveal that the electrolyte layer is most likely to crack. The maximum tensile stress in the electrolyte (adjacent to the anode) reaches $\approx 180 \mathrm{MPa}$ if the membrane is composed of three $20 \mu \mathrm{m}$ layers and heated with the maximum heating power (Figure 8a). Even if the electrolyte layer is broadened to $3000 \mu \mathrm{m}$, the maximum tensile stress is still $\approx 50 \mathrm{MPa}$, which is very close to the tensile strength of SDC. Under the same conditions, the tensile stress in the cathode and the compressive stress in the anode change from $\approx 40 \mathrm{MPa}$ to less than $10 \mathrm{MPa}$ and, therefore, never reach the tensile or compressive strength of LSC and Ni/SDC, respectively. In order to improve the survival chances of the electrolyte, the heating rate has to be reduced. If the heaters are powered with $150 \mathrm{~V}$, an electrolyte thickness of $\approx 2 \mathrm{~mm}$ or more is enough to avoid the exceeding overcritical tensile stress. Powering the heaters with $150 \mathrm{~V}$ indeed results in a reduced heating rate. However, even with the reduced heating rate, the SOFC operating temperature of $700{ }^{\circ} \mathrm{C}$ is reached in $540 \mathrm{~s}$, which favours the developed SOFC testing system for quick test cycles.

If the thicknesses of the electrolyte and cathode layers are kept constant, and the anode layer is broadened from $20 \mu \mathrm{m}$ to $3000 \mu \mathrm{m}$, the built maximum tensile stresses in the electrolyte are rather high (Figure $\mathbf{8 b}$ ). In all the investigated membrane designs, they exceed the tensile strength of SDC. It appears that the relatively large difference in the thermal-expansion coefficients between $\mathrm{Ni} / \mathrm{SDC}$ and SDC and the thick anode layer substantially reduce the chances of the multi-layer system to survive the heating. In order to reduce the probability of failure in the anode-supported membrane, the design heating rate must be further decreased.

\section{CONCLUSIONS}

A new SOFC system enabling quick testing cycles was developed and successfully described using the finite-element modelling. It was shown that Ni/SDCSDC-LSM membranes were subjected to temperature gradients during the heating. These gradients were pri- 
marily caused by the heating mode in the testing system, where hot gases circulated inside the anode and cathode compartments and caused non-uniform membrane heating. The critical point with respect to a membrane failure was recognized during the early stage of the system heating when the temperature gradients in the membrane were the largest. During the heating, the electrolyte and cathode were always under a tensile stress, while the anode was under a compressive stress. The maximum thermally induced stress during the heating was observed in the electrolyte layer adjacent to the anode/electrolyte phase boundary. The absolute values of the induced maximum stress increased with the increasing diameter of the membrane. Additionally, the electrolyte-supported membranes had greater chances of surviving rapid temperature increases. In an electrolyte layer of $\approx 2 \mathrm{~mm}$ or more, the SDC tensile stress was never exceeded even if the system was heated with the maximum power. The anode-supported membranes, in contrast, were much more prone to cracking due to a relatively large difference between the thermal-expansion coefficients of the $\mathrm{Ni} / \mathrm{SDC}$ anode and SDC electrolyte. Even a somewhat reduced heating rate still induced the occurrence of overcritical tensile stresses in the electrolyte. To reduce the probability of an anode-supported membrane failure, the heating power in the testing system should be further lowered, at least during the early stage of the membrane heating.

\section{REFERENCES}

${ }^{1}$ S. M. Haile, Acta Mater., 51 (2003) 19, 5981-6000, doi:10.1016/ j.actamat.2003.08.004

${ }^{2}$ F. Tietz, I. Arul Raj, W. Jungen, D. Stöver, Acta Mater., 49 (2001) 5 , 803-810, doi:10.1016/S1359-6454(00)00385-2

${ }^{3}$ T. Suzuki, Z. Hasan, Y. Funahashi, T. Yamaguchi, Y. Fujishiro, M. Awano, Sci. Mag., 325 (2009) 5942, 852-855

${ }^{4}$ Y. Yin, S. Li, C. Xia, G. Meng, Electrochim. Acta, 51 (2006), 2594-2598, doi:10.1016/j.electacta.2005.07.046

${ }^{5}$ J. Li, T. Ikegami, T. Mori, Acta Mater., 52 (2004), 2221-2228, doi:10.1016/j.actamat.2004.01.014

${ }^{6}$ J. Wright, A. Virkar, J. Power Sources, 196 (2011), 6118-6124, doi:10.1016/j.jpowsour.2011.03.043

${ }^{7}$ J. Cheng, L. Deng, B. Zhang, P. Shi, G. Meng, Rare Metals, 26 (2007), 110-117, doi:10.1016/S1001-0521(07)60169-7

${ }^{8}$ M. Chen, B. H. Kim, Q. Xu, B. K. Ahn, W. J. Kang, D. P. Huang, Ceram. Int., 35 (2009), 1335-1343, doi:10.1016/j.ceramint.2008. 06.014

${ }^{9}$ Q. Liu, X. Dong, C. Yang, S. Ma, F. Chen, J. Power Sources, 195 (2010), 1543-1550, doi:10.1016/j.jpowsour.2009.09.071
${ }^{10}$ M. Chen, B. H. Kim, Q. Xu, O. J. Nam, J. H. Ko, J. Eur. Ceram. Soc., 28 (2008), 2947-2953, doi:10.1016/j.jeurceramsoc.2008.05. 009

${ }^{11}$ X. Fang, G. Zhu, C. Xia, X. Liu, G. Meng, Solid State Ionics, 168 (2004), 31-36, doi:10.1016/j.ssi.2004.02.010

${ }^{12}$ Y. Yin, W. Zhu, C. Xia, G. Meng, J. Power Sources, 132 (2004), 36-41, doi:10.1016/j.jpowsour.2004.01.017

${ }^{13}$ C. M. Grgicak, R. G. Green, W. F. Du, J. B. Giorgi, J. Am. Ceram. Soc., 88 (2005), 3081-3087, doi:10.1111/j.1551-2916.2005.00544.x

${ }^{14}$ W. Fischer, J. Malzbender, G. Blass, R. W. Steinbrech, J. Power Sources, 150 (2005), 73-77, doi:10.1016/j.jpowsour.2005.02.014

${ }^{15}$ C. R. He, W. G. Wang, J. Wang, Y. Xue, J. Power Sources, 196 (2011), 7639-7644, doi:10.1016/j.jpowsour.2011.05.025

${ }^{16}$ K. P. Recknagle, R. E. Williford, L. A. Chick, D. R. Rector, M. A. Khaleel, J. Power Sources, 113 (2003), 109-114, doi:10.1016/ S0378-7753(02)00487-1

${ }^{17}$ L. Petruzzi, S. Cocchi, F. Fineschi, J. Power Sources, 118 (2003), 96-107, doi:10.1016/S0378-7753(03)00067-3

${ }^{18}$ M. Ambrožič, K. Vidovič, Mater. Tehnol., 41 (2007) 4, 179-184

${ }^{19}$ O. C. Zienkiewicz, R. Taylor, The Finite Element Method: Volumes $1,2 \& 3,5^{\text {th }}$ ed., Elsevier, Butterworth-Heinemann, 2000

${ }^{20}$ J. N. Reddy, An Introduction to the Finite Element Method, McGraw-Hill, 1993

${ }^{21}$ K. J. Bathe, Finite Element Procedures, Prentice Hall, Englewood Cliffs, New Jersey 1996

${ }^{22}$ A. Selimovic, M. Kemm, T. Torisson, M. Assadi, J. Power Sources, 145 (2005), 463-469, doi:10.1016/j.jpowsour.2004.11.073

${ }^{23}$ C. K. Lin, T. T. Chen, Y. P. Chyou, L. K. Chiang, J. Power Sources, 164 (2007) 4, 238-251, doi:10.1016/j.jpowsour.2006.10.089

${ }^{24}$ T. Skalar, M. Marinšek, M. Lubej, T. Skalar, M. Lukežič, J. Maček, Mater. Tehnol., 48 (2014) 6, 861-867

${ }^{25}$ T. Skalar, A. Golobič, M. Marinšek, J. Maček, Mater. Tehnol., 47 (2013) 4, 423-429

${ }^{26}$ T. Skalar, J. Maček, A. Golobič, J. Eur. Ceram. Soc., 32 (2012), 2333-2339, doi:10.1016/j.jeurceramsoc.2012.02.008

${ }^{27}$ M. Marinšek, Mater. Tehnol., 43 (2009) 2, 79-84

${ }^{28}$ I. S. Liu, Continuum Mechanics, Springer, 2002, doi:10.1007/978-3662-05056-9

${ }^{29}$ S. W. Churchill, H. H. S. Chu, Int. J. Heat Mass Transfer, 18 (1975), 1323, doi:10.1016/0017-9310(75)90243-4

${ }^{30}$ G. K. Batchelor, An Introduction to Fluid Dynamics, Cambridge University Press, 1967

${ }^{31}$ S. Sameshima, T. Ichikawa, M. Kawaminami, Y. Hirata, Mater. Chem. Phys., 61 (1999), 31-35, doi:10.1016/S0254-0584(99) 00109-1

${ }^{32}$ X. B. Li, H. Y. Wang, H. X. Gu, J. Wang, W. J. Zhang, T. G. Wang, Sci. Sinter., 42 (2010), 153-159, doi:10.2298/SOS1002153L

${ }^{33}$ Y. X. Gan (Ed.), Continuum mechanics - Progress in fundamentals and engineering applications, InTech, Rijeka, Croatia 2012, doi: $10.5772 / 2103$

${ }^{34}$ R. Cutler, D. Meixner, Solid State Ionics, 159 (2003), 9-19, doi:10.1016/S0167-2738(03)00006-7 